\title{
The Identification of Carotenoids and Testing of Carotenoid Antioxidants from Sand Lobster (Panulirus homarus) Egg Extract
}

\author{
James Ngginak ${ }^{1}$, Jubhar C. Mangibulude ${ }^{2}$ and Ferdy S. Rondonuwu ${ }^{1,3 *}$ \\ ${ }^{1}$ Graduate Program of Biology, Satya Wacana Christian University, \\ Jl. Diponegoro 52-60, Salatiga, Indonesia 50711 \\ 2Engineering Technology and Natural Science Faculty, Halmahera University, \\ Jl. Wari-ino, Tobelo, Indonesia 97762 \\ ${ }^{3}$ Faculty of Science and Mathematics, Satya Wacana Christian University, \\ Jl. Diponegoro 52-60, Salatiga, Indonesia 50711 \\ Email: ferdy@staff.uksw.edu
}

\begin{abstract}
Sand lobsters (Panulirus homarus) are organisms that play an important role in supporting a society's economy. Lobsters have a business appeal due to their high demand, enjoyable taste, as well as significant nutritional content. It is interesting that sand lobster eggs have a yellow orange color as an indicator of the presence of carotenoid content. Related with advancements in research and the utilization of carotenoids, this research identifies carotenoids and tests carotenoid antioxidants from sand lobster (Panulirus homarus) egg extract. In identifying carotenoids in sand lobster egg extract, HPLC (high performance liquid chromatography) (shimadzu LC-10AD, Japan) is used. In testing carotenoid antioxidants from sand lobster eggs, a DPPH method is utilized. The identification results with HPLC reveal that the sample contains carotenoids. The kinds of carotenoids identified are dinoxanthin, diadinoxanthin, zeaxanthin, lutein, astaxanthin, and violaxanthin. Among the six kinds of carotenoids identified, lutein is the type of carotenoid that has the highest concentration. These carotenoid compounds are detected in wavelengths of $400-500 \mathrm{~nm}$. The test results of antioxidant power reveal that to hamper free radicals (IC50), a sample concentration of $6675.25 \mu \mathrm{g} . \mathrm{ml}^{-1}$ is needed. The ability to hinder free radicals from a sample extract is mostly conducted by lutein, zeaxanthin, and astaxantin. If seen from the analytical results, it can be surmised that sand lobster eggs contain carotenoids that can be used as a carotenoid source for humans.
\end{abstract}

Keywords : Sand Lobster, HPLC, Carotenoids, DPPH, Antioxidant

\section{Introduction}

The tropical characteristic of the archipelago water makes it possible for various kinds of lobsters to live, including sand lobsters (Panulirus homarus). The distribution of this lobster species is supported by the presence of several other kinds of lobsters like tropical rock lobsters (Panulirus ornatus), pronghorn spiny lobsters (Panulirus penicillatus), scalloped spiny lobsters (Panulirus homarus), and painted spiny lobsters (Panulirus versicolor), which are societal cultivation objects (Subani et al., 1993). It can be said that Indonesian waters are an appropriate climate for lobsters to grow and develop.

Sand lobsters are from the crustacean family and have the potential to stimulate economic and industrial advancements. The increasing demand and high nutritional content make sand lobsters a business and source of income for society. Statistical data from Ditjenkan (2011) reveals that lobsters are considered as an Indonesian export commodity. Sand lobsters (Panulirus homarus) are considered as a species which has an export value of up to US $\$ 13$ million with prices of US $\$ 6-7 . \mathrm{kg}^{-1}$ (Anonymous 2011a; 2011b). Thus, lobsters do not just drive the society's economy, but they are also a source of state foreign exchange.

One of the important compounds in a lobster's body is carotenoids. These are a group of organic pigments that are fat soluble. Based on the arrangement of components, carotenoids can be divided into two pigment groups, which are xanthophyll (has $\mathrm{C}, \mathrm{H}, \mathrm{O}$ atoms) and carotene (has $\mathrm{C}$, $\mathrm{H}$ atoms). For instance, the xanthophyll group has astaxanthin $\left(\mathrm{C}_{40} \mathrm{H}_{52} \mathrm{O}_{4}\right)$. An example of carotene is $\beta$ carotene $\left(\mathrm{C}_{40} \mathrm{H}_{56}\right)$ (Britton, 1995). In general, carotenoids cannot be synthesized by animals, including lobsters (Urzua et al., 2011). Carotenoids are available in lobsters through food intake. In a lobster's body, carotenoids play a vital role like in camouflage, status, and mating attraction (Tlusty et 
al., 2005). One of the carotenoid pigments that are contained within and play a role in lobster metabolism is astaxanthin. Besides astaxanthin (3.3-dihydroxy-beta, beta-carotene-4.4-dione), there is also crustacyanin (complex protein), which plays a role in determining a lobster's color (Chayen et al., 2000). All of these pigment cells work to determine the color of a lobster's body. These cells are placed in tissues below the epidermis. Based on the description above, it is clear that environmental factors and a lobster's body's metabolism sustainability are two significant components in carotenoid accumulation.

Carotenoids also have an important function in supporting human health. According to Gross (1991), carotenoids are useful as antioxidants, cardiovasculer deterrents, osteoporosis, diabetes, as well as natural colorants. The antioxidant ability of carotenoids is utilized to develop the cosmetics and pharmacy industries (Anunciato et al., 2012). Thus, a carotenoid application is a significant part in human civilizations.

Based on the background above, the goal of this research is to determine the carotenoid composition of sand lobster (Panulirus homarus) eggs as well as test carotenoid antioxidants of sand lobster eggs.

\section{Material and Methods}

This research is conducted to identify the carotenoid content of sand lobster eggs and test the carotenoid antioxidant power of sand lobster eggs. The sample used is sand lobster (Panulirus homarus) eggs which are retrieved from a southern beach (Pok Tunggal) in Yogyakarta. The chemical ingredients used consist of methanol, ethyl ether, acetone, $\mathrm{KOH}, \mathrm{C}_{6} \mathrm{H}_{8} \mathrm{O}_{6}, \mathrm{NaCl}$, and DPPH.

\section{Extraction}

Before the extraction process, a sample is kept for $1 \times 24$ hours in the refrigerator. A 20 g sample (wet) that has been prepared is crushed with a mortar and pestle until it is refined. Next, the refined sample is extracted using a dissolvent with $50 \mathrm{ml}$ of methanol. The extraction process is repeated once and accompanied with a stirrer to separate the pigments. The extracted pigments are gathered. Then $\mathrm{C}_{6} \mathrm{H}_{8} \mathrm{O}_{6} 1 \mathrm{~g}, \mathrm{NaCl} 1 \mathrm{~g}$, and $10 \mathrm{ml} \mathrm{KOH} \mathrm{60 \%} \mathrm{are}$ added and stirred again for 2 minutes. The pigments are then filtered using Whatman paper no. 1 . The filtrate that is obtained is put into separating funnel, added with $30 \mathrm{ml}$ of ethyl ether to separate it. The ethyl ether part is separated and then taken and filtered. For the next stage, the filtrate is steamed with nitrogen gas $\left(\mathrm{N}_{2}\right)$ until it is dry and ready to be analyzed (Khanafari et al., 2007).

\section{Carotenoid Identification Using HPLC}

The pigment content from sand lobster egg extract is analyzed with High Performance Liquid Choramtography. The dry sample from the available extraction is dissolved with a methanol 100\% dissolvent. A $20 \mu \mathrm{l}$ sample is injected into HPLC (shimadzu LC-10AD Japan) with a column C18 $\mu$ reverse phase (a diameter of $3.9 \mathrm{~mm}$ id $\times 30 \mathrm{~cm}$ ). A motion phase consists of methanol: acetone $(90: 10$ $\mathrm{V} . \mathrm{V}^{-1}$ ) with a flowing speed of $1 \mathrm{ml} \cdot \mathrm{min}^{-1}$. A running sample is carried out for 40 minutes in a long wave interval of 300-600 nm (Parisenti et al., 2011).

\section{Antioxidant (DPPH) Activity Test}

The antioxidant activity test begins by making a series of concentrations of 5000, 1000, 1500, 2000, 2500, and $3000 \mu \mathrm{g} \cdot \mathrm{ml}^{-1}$. After making the concentration series, next a sample concentration series is devised. A sand lobster egg extract concentration of $8780 \mu \mathrm{l} . \mathrm{ml}^{-1}$, which is dissolved in methanol, has a concentration series made each consisting of $114,228,342,456,570$, and $684 \mu \mathrm{l}$. The sample which has had its concentration arranged is given $3 \mathrm{ml} \mathrm{(1:3)}$ of diphenil -2picryllhydrazil (DPPH) $0.1 \mathrm{mM}$. The next mixture is homogenized with a vortex for 1 minute as well as incubated for 30 minutes. After this, its absorbance is measured in wavelengths of $517 \mathrm{~nm}$ after measuring blank absorbance with methanol. The measurement uses a U-1240 Shimadzu mini UV spectrophotometer (Banerjee et al., 2005). The percentage of obstruction can be calculated with the formula: $\%$ of obstruction $=$

$$
\frac{\text { Abs.Blank - Abs.Sample }}{\text { Abs.Blank }} \times 100 \%
$$

\section{Data Analysis}

The data obtained is analyzed using Matlab R2013a and OriginPro v9.0. The analysis results are compared with a reference (Jeffrey et al., 1997).

\section{Results and Discussion}

An identification of carotenoid pigments from a sand lobster egg sample using HPLC reveals that the pigments identified are from the xanthophyll group of carotenoids. The carotenoid content in the sample is strengthened with the presence of an absorption region in the 400-500 $\mathrm{nm}$ interval as a carotenoid absorption area (Britton, 1995). The 
presence of this carotenoid compound is supported by a yellow extract color. The kinds of carotenoids that are identified in the sample can be seen in the HPLC chromatogram profile figure below.

Based on the HPLC chromatogram profile in Figure 1 above, it shows that not all chromatogram peaks are identified, so that it can be assumed that the unidentifiable peaks are those which have experienced degradation. The peak levels depict the concentrations of the compounds. After comparison tests are done with references, there are 6 peaks identified as carotenoids. The 6 peaks consist of dinoxanthin, diadinoxanthin, zeaxanthin, lutein, astaxanthin, and violaxanthin. The HPLC chromatogram profile reveals that lutein has the highest peak. This clarifies the high concentration of the lutein compound. The high lutein concentration is not separate from the dissolvent role in maintaining the lutein integrity. The level of methanol polarity that approaches the lutein polarity keeps lutein stabile. Using this kind of a dissolvent in an HPLC analysis is one of the components that influence absorption and concentration through an elution power and resolution process. The elution power and resolution is determined by the polarity of the whole dissolvent. In an HPLC analysis, a mixture of methanol dissolvent is used: acetone $90: 10$ as a motion phase. Lutein is a carotenoid that is included in the xanthophyll group. This compound has 9 until 13 conjugated bonds. By having these conjugated bond chains, it makes lutein able to be degraded and also function as an antioxidant in a biological system (Young and George, 1993). The chemical structure of lutein that has a dominant hydroxyl cluster is a special characteristic of the lutein compound. The presence of a hydroxyl cluster in lutein makes a lutein compound more polar compared with $\alpha-, \beta$-carotene.
A profile of the analysis results regarding the carotenoid pigment composition of sand lobster eggs is provided in Table 1 below. The sample peaks of the HPLC chromatogram are identified based on comparisons with the reference.

In referring to the reference of Jeffrey et al. (1997), with an absorbance of 416, 438, and 467 $\mathrm{nm}$, then the first peak of the sample with an absorbance of 420,442 , and $472 \mathrm{~nm}$ is identified as a dinoxanthin type of carotenoid. For the second spectrum based on the reference of Jeffrey et al. (1997), with an absorbance of 445.5 and $474 \mathrm{~nm}$, then the second peak of the sample with an absorbance of 421,449 , and $474 \mathrm{~nm}$ is identified as a diadinoxanthin type of carotenoid. Next, for the third peak based on the reference of Jeffrey et al. (1997), with an absorbance of 422, 450, and 481 $\mathrm{nm}$, then the third peak of the sample with an absorbance of 415,449 , and 474 is identified as a zeaxanthin type of carotenoid.

For the fourth spectrum, if the standard in the reference of Jeffrey et al. (1997) has an absorbance of 418,444 , and $474 \mathrm{~nm}$, then the fourth peak of the sample with an absorbance of 417,443 , and 472 is identified as a lutein type of carotenoid. Next, for the fifth peak based on the reference of Jeffrey et al. (1997), with an absorbance of $478 \mathrm{~nm}$, then the fifth spectrum of the sample with an absorbance of 474 is identified as an astaxanthin type of carotenoid. Then for the sixth peak departing from the reference of Jefrrey et al. (1997), with an absorbance of 415,440 , and $469 \mathrm{~nm}$, the sixth spectrum of the sample with an absorbance of 414 , 439 , and $464 \mathrm{~nm}$ is identified as a violaxanthin type of carotenoid.

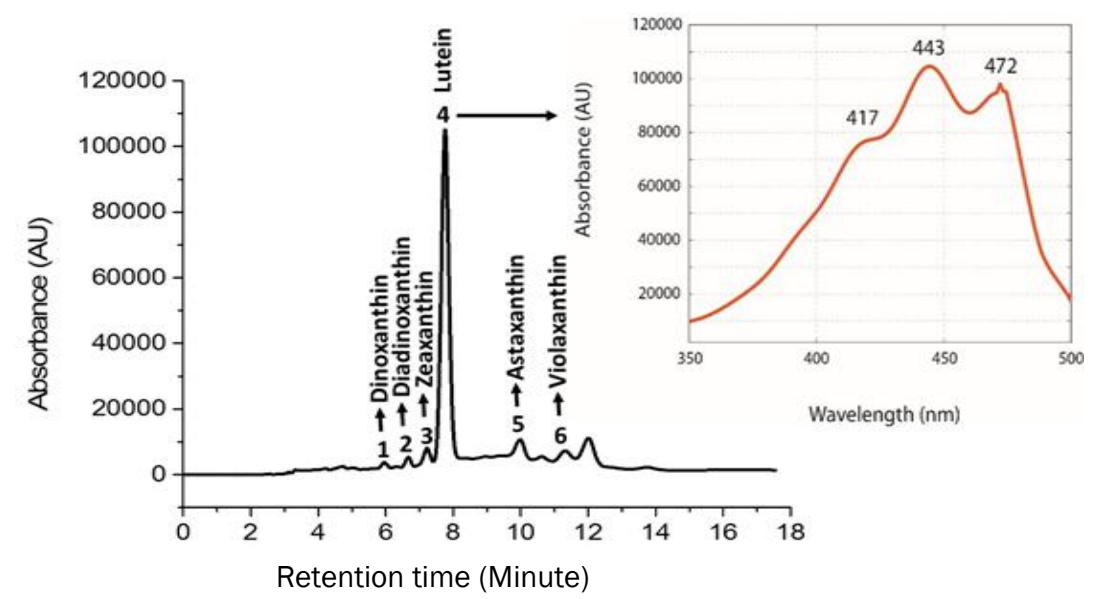

Figure 1. The HPLC chromatogram profile of sand lobster (Panulirus homarus) egg extract which has 6 peaks is identified by observing the spectrum in the $446 \mathrm{~nm}$ wavelength. Among the 6 peaks, the lutein compound concentration is most dominant compared with the other 5 compounds: dinoxanthin, diadinoxanthin, zeaxanthin, astaxanthin, and violaxanthin. 
Table 1. The Composition of Sand Lobster (Panulirus homarus) egg extrat pigment 400-500 nm

\begin{tabular}{|c|c|c|c|c|c|c|c|}
\hline \multirow{2}{*}{ No } & \multirow{2}{*}{ Minute } & \multicolumn{3}{|c|}{ Absorbance } & \multirow{2}{*}{ Solvent } & \multirow{2}{*}{ Pigment } & \multirow{2}{*}{ Reference } \\
\hline & & 1 & II & III & & & \\
\hline 1 & 5,97 & 420 & 442 & 472 & Methanol & Dinoxanthin & Loeblich, and Smith(1968) \\
\hline 2 & 6,66 & 421 & 449 & 474 & Methanol & Diadinoxanthin & Johansen et al. (1974) \\
\hline 3 & 7,23 & 415 & 449 & 474 & Methanol & Zeaxanthin & Karrer, and Jucker(1948) \\
\hline 4 & 7,75 & 417 & 443 & 472 & Methanol & Lutein & Karrer, and Jucker(1948) \\
\hline 5 & 9,97 & & 474 & & Methanol & Astaxanthin & Repeta, and Gagosian(1982) \\
\hline 6 & 11,31 & 414 & 439 & 464 & Methanol & Violaxanthin & Karrer, and Jucker(1948) \\
\hline
\end{tabular}

Looking at the data from the sample analysis results and the reference data above, there is a clear shift in absorbance between the sample and reference as a comparison. This shift can be caused by the methanol dissolvent correction factor that can move 1-8 $\mathrm{nm}$ (Britton, 1995), and it can also be influenced by the high and low sample concentration value. This absorbance shift, according to Britton (1995), is a chromophore interaction that is bound as carotenoid hydrophobic molecules, so that there is a band shift to another direction which causes absorption value differentiation. In addition, the absorbance shift is also influenced by the presence of an electron $\pi$ to $\Pi^{*}$ transition, where one of the bound electrons from a conjugated system is excited from the $\pi$ orbital to its $\pi^{*}$ antibody orbital. In the carotenoid compound, the $\pi$ electron is significantly delocalized, keeping in mind that its dual bound conjugated system is very long. This causes an excitation process to occur with relatively low energy, so that in general the carotenoid compound becomes more colorful and has the potential to experience a shift in absorbance (Britton, 1995).

It is also explained by Keenan (2005, in Susilowati, 2008) that the occurrence of a shift in wavelengths as well as absorbance between the sample with literature as a comparison is caused by the presence of electron transitions. Electrons which are easily excited by light it appears are usually found in a molecule that has several atoms connected by alternating double and single bonds. This kind of a process causes differences in the sample absorbance with reference.

\section{Antioxidant Test (DPPH)}

An antioxidant test of sand lobster (Panulirus homarus) eggs is conducted by determining the value $\%$ of inhibition $\left(\mathrm{IC}_{50}\right)$. The inhibition concentration $\left(\mathrm{IC}_{50}\right)$ is a dissolved concentration that provides DPPH inhibited power of $50 \%$. The $\mathrm{IC}_{50}$ value is used to reveal the antioxidant activity of a tested material with a DPPH free radical inhibition method (Molyneux, 2004).
Table 2 describes making a sample concentration series, measuring a DPPH solution, blank, and value of inhibited percentage obtained. The inhibition percent values of each carotenoid extract concentration can be seen in Table 2 .

The $\mathrm{IC}_{50}$ value is calculated by interpolating the percentage of inhibition (50\%) inside the curve of the relationship between the test solution concentration with the percentage of inhibition. From the data between the solution concentration and inhibition percentage, a regression line formula is devised. The Inhibition Concentration (IC50) Curve or inhibition value $\%$ is the $Y$ axis and the concentration series is the $X$ axis. The curve in the relationship between the test solution and the inhibition percentage can be seen in Figure 2.

Based on the data of the DPPH analysis above, to reach the $\mathrm{IC}_{50}$ value, a sample concentration value of $6675.25 \mu \mathrm{g} . \mathrm{ml}^{-1}$ is needed. In other words, the sample concentration value is $6675.25 \mu \mathrm{g} . \mathrm{ml}^{-1}$ as a value that is able to inhibit free radicals. This value is obtained by using a linear equation above. It can be concluded that the concentration value which progressively increases, has a correlation or is linear with the inhibition value that is connected in the linear line. The inhibition of free radicals from sand lobster egg extract is determined by various antioxidant compounds that are contained in sand lobster egg extract.

Referring to the lutein HPLC data as pigments which have a high concentration, it is ascertained to have a big contribution in inhibiting free radicals. Lutein and astaxanthin are two kinds of carotenoids that have good free radical inhibition power. The capacity to inhibit free radicals was emphasized in research results by Mozaffarieh et al. (2003) and Madhavi and Kagan (2002), who claimed that consuming 6-20 $\mathrm{mg}$ of lutein can prevent the occurrence of oxidative reactions in the eyes. Darlington and Stone (2000), mentioned that astaxanthin has a poliene chain that is able to absorb free radicals that cause cellular structure macromolecular disruptions. Besides the role of lutein and astaxanthin, other kinds of carotenoids 
Table 2. Data of inhibition percentage from each sample concentration

\begin{tabular}{ccccc}
\hline$\left[\mu \mathrm{g} \cdot \mathrm{ml}^{-1}\right]$ & A517nm & Afk & A(count) & \% Inhibition \\
\hline 0 & 0,719 & 0 & 0,719 & 0 \\
500 & 0,721 & 0,006 & 0,715 & 0,556328 \\
1000 & 0,698 & 0,012 & 0,686 & 4,589708 \\
1500 & 0,675 & 0,019 & 0,656 & 8,76217 \\
2000 & 0,657 & 0,028 & 0,629 & 12,51739 \\
2500 & 0,635 & 0,036 & 0,599 & 16,68985 \\
3000 & 0,617 & 0,046 & 0,571 & 20,58414 \\
\hline
\end{tabular}

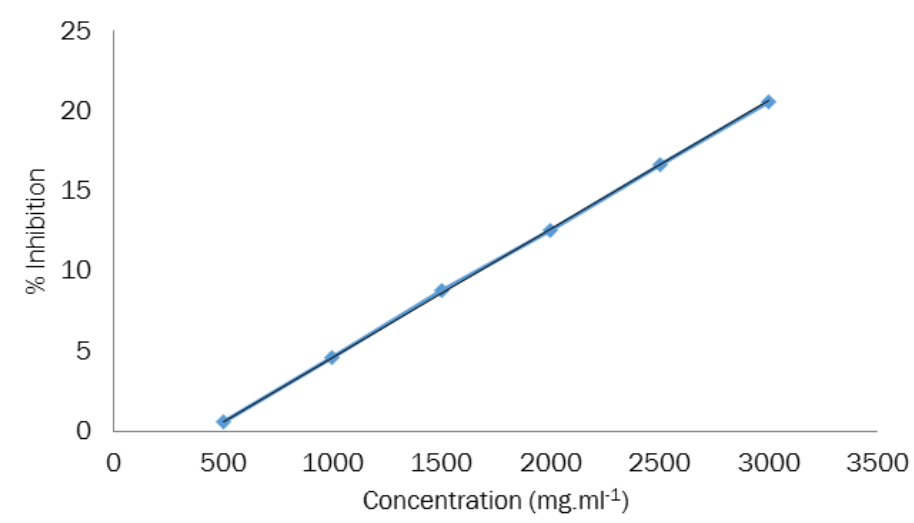

Figure 2. The curve in the relationship between a carotenoid test solution and inhibition percentage. The inhibition power ( $y$ ) as a function as concentration $(x)$ is obtained from the formula $y=a x+b$. The value of the coefficient $a$ is $8 \times 10^{-3}$, and the value of coefficient $b$ is -3.4 .

like zeaxanthin also have the capacity to be good antioxidants. Thus, it is appropriate that the sample used for an antioxidant test has the capacity to inhibit free radicals.

The ability to exhibit good antioxidant power from carotenoids clearly opens development opportunities in the cosmetics, pharmacy, and food industries (Anunciato et al., 2012). In the future, it is expected that developing carotenoid applications can respond to societal needs. It is also hoped that society realizes the importance of consuming lobsters.

\section{Conclusion}

Based on the research data and identification results, it can be concluded that carotenoids are contained in sand lobster (Panulirus homarus) eggs. The dominant carotenoids are the xanthophyll group carotenoids. The carotenoid antioxidant test from sand lobster eggs reveals there is an ability to counter free radicals. Looking at the capacity of the sand lobster (Panulirus homaus) egg sample, in the future it is hoped that society utilizes sand lobsters (Panulirus homarus) as well as possible as a carotenoid source to fulfill nutritional intake.

\section{Acknowledgment}

Gratitude is conveyed to the Indonesia National Education Department for providing a scholarship through the Satya Wacana Christian University Biology Master's Degree Scholarship Program in Salatiga.

\section{References}

Anonymous. 2011a. Statistik Ekspor Hasil Perikanan. Buku I. Kementerian Kelautan dan Perikanan.524p

Anonymous. 2011b. Statistik Ekspor Hasil Perikanan. Buku II. Kementerian Kelautan dan Perikanan. $446 p$

Anunciato, T.P., da Rocha, Filho. PA. 2012. Carotenoids and polyphenols in nutricosmetics, nutraceuticals, and cosmeceuticals. Department of Pharmaceutical Sciences, Faculty of Pharmaceutical Sciences of Ribeirão Preto, University of São Paulo, Brasil. (51-53)

Banerjee, A., Dasgupta, N. \& De, B. 2005. In Vitro Study of Antioxidant Activity of Syzigiumcumini Fruit. J. Food Chemistry. 90:727-733 
Britton, G. 1995. Structure and properties of Carotenoids in relation to function. Department of Biochemistry University of Liverpool. United Kingdom

Chayen, N.E., Cianci, M., Grossmann, G., Habas, J., Helliwell, J.R., Nneji, G.A., Raftery, J., Rizkallah, P.J. \& Zagalzky, P.F. 2003. Unravelling the Structural Chemistry of the Colouration Mechanism in Lobster Shell. Imperial College London, Daresbury Laboratory London, Depertemen of chemistry University Manchester London

Darlington, G.L. \& Stone, W.T. 2001. Antioxidants and Fatty Acids in the Amelioration of Rheumatoid arthritis and Related Disorders. Epsom General Hospital, Dorking Rd, UK. Institute of Biomedical and Life Sciences, University of Glasgow, Glasgow UK. British. J. Nutrition. 85:251-269. doi: 10.1079/BJN200 0239

Ditjenkan. 2011. Kelautan dan Perikanan Dalam Angka. Kementerian Kelautan dan Perikanan, Pusat Data Statistik dan Informasi. Jakarta (2935)

Gross, J. 1991. Pigments in Vegetables Chlorophylls and Carotenoids. Information Systems Division, National Agricultural Library (United States of America) NAL/USDA. Van Nostrand Reinhold,New York. USA

Jeffrey, S. W., Mantoura, R.F.C. \& Wright, S.W. 1997. Phytoplankton Pigments in Oceanography: Guidelines to modern methods. International Council of Scientific Unions. Committe on Oceanic Research UNESCO

Johansen, J. E., Svec, W. A., Liaaen-Jensen, S., \& Haxo, F.T. 1974. Carotenoids of the Dinophyceae. Phytochem. 13:2261-2271

Karrer, P., \& Jucker, E. 1948. Carotenoide. Basel : Birk - hauser

Keenan, C. 2005. IImu Kimia Untuk Universitas Jilid 2. Universitas Negeri Malang. Erlangga. Indonesia

Khanafari, A., Saberi, A., Azar, M., Vosooghi, Gh., Jamili, Sh. \&, Zabbaghzadeh. 2007. Extaction of Astaxanthin esters from Shrimp Waste by Chemichal and Microbal Methods. Depertement of Microbiological Sciences, Islamic Azad University, North of Tehran. Iran. (93-97)
Loeblich, A. R., \& Smith, V. E. 1968. Chloroplast pigments of the marine dinoflagellate Gyrodinium splandes. Lipids 3:5-13

Madhavi, D.L. \& Kagan, D.I., 2002. Process For The Isolation Of Mixed Carotenoids From Plants. United States Pantent Documents, United States. 6(380):442

Molyneux, P. 2004. The use of the stable free radical diphenylpicryl-hydrazyl (DPPH) for estimating antioxidant activity. Songklanakarin J. Sci. Technol. 26:211-219

Mozaffarieh, M., Sacu, S. \& Wedrich, A. 2003. The Role of The Carotenoids, Lutein And Zeaxanthin, In Protecting Against Age-Related Macular Degeneration: A Review Based On Controversial Evidence, Nutrition Journal 2(20). Austria: Department of Ophthalmology, University of Vienna

Parisenti, J., Beirão, L.H., Maraschin, M., Mouriño, J.L., Do Nascimento Vieira, F., Bedin, L.H. \& Rodrigues, E. 2010. Pigmentation and carotenoid content of shrimp fed with Haematococcus pluvialis and soy lecithin. Universidade Federal de Santa Catarina (UFSC), Pós-graduação em Ciência dos Alimentos. Florianópolis.Brasil. (530-534)

Repeta, D. J., Gagosian, R. B. 1982. Carotenoid tranformations in coastal marine waters. Nature, Lond. 295:51-54

Subani, W., Rijal, M. \& Suman, A. 1993. Status Perikanan Udang Karang di Perairan Pangandaran Jawa Barat. Jurnal Penelitian Perikanan Laut. Jakarta. (1-5)

Susilowati, 2008. Isolasi dan Identifikasi Senyawa Karotenoid dari Cabai Merah (Capsicum annuum Linn).UIN Malang. Indonesia

Tlusty, M. \& Hyland, C. 2005. Astaxanthin deposition in the cuticle of juvenile American lobster (Homarus americanus): implications for phenotypic and genotypic coloration. Marine Biology. Boston. USA. (113-119)

Urzua, A., Paschke, K., Gebauer, P. \& Anger, K. 2011. Seasonal and interannual variations in size, biomass and chemical composition of the eggs of North Sea shrimp, Crangon crangon (Decapoda: Caridea). Biologische Anstalt Helgoland. Alfred-Wegener Institu fur polar un Meeresforschung. Germany

Young, A. \& George, B. 1993. Carotenoids in Phosinthesis. Chapman and Hall, London. 1-6 and 110-112 